\title{
Value of innovation to enhance marketing performance (clarification)
}

\author{
Suliyanto Suliyanto ${ }^{1 *}$, Rahab Rahab ${ }^{1}$, and Mansur Chadi Mursid ${ }^{2}$ \\ ${ }^{1}$ Faculty of Economics and Business, Jenderal Soedirman University, Indonesia \\ ${ }^{2}$ Faculty of Islamic Economics and Business, Institut Agama Islam Negeri (IAIN) Pekalongan, \\ Indonesia
}

\begin{abstract}
The purpose of this paper is to analyze value of innovation as the role mediating in the relationship between NPD Innovation and NPD Performance, and also to clarified in Exploratory Factor Analysis and Confirmatory Factor Analysis. We proposed value of innovation basis on shariah as mediating role in this study developed from diffusion of innovations theory. The questionnaires will be given to only the managers of the board of shariah micro finance in Pekalongan and Banyumas, Indonesia with total 171 responden from 27 LKMS (Baitul Maal wa Tamwil, Baitul Tamwil, Kospin Jasa Shariah, and KSPP Shariah). Value of innovation basis on shariah significantly affect to marketing performance. Research limited in first order, future research can examined in second order research. LKMS adapted value of innovation basis on shariah to get product launch easily. Value of innovation basis on shariah as the new variable and theory concept. Indirect, NPD Innovation positive significantly affect to marketing performance with value of innovation basis on shariah and product launch success are as mediating role.
\end{abstract}

\section{Introduction}

Studies have provided various perspectives on the performance effect of product innovativeness, and several scholars have argued that product innovativeness positively affects new product performance (Mishra, Kim, \& Lee, 1996; Atuahene-Gima, 1996; Hultink \& Robben, 1995; Fang, 2008; Akroush, 2012; Millson, 2013; Bicen, Kamarudin \& Johnson, 2014; Santos, Basso, Kimura \& Kayo, 2013; Huang \& Tsai, 2014; Vinayak \& Kodali, 2014; and Warren, 2017). Conversely, several studies have indicated that product innovativeness is negatively associated with new product performance. Buyers may be averse to new products with a high degree of innovativeness because of a heightened potential of social, performance, or financial risks that accompany the purchase of such products (Sethi, 2000). Several studies have also observed that product innovativeness does not influence new product performance (Calantone et. al., 2006), unidentified (Santos, et. al., 2013), whereas other evidence supports the hypothesis that a negative effect occurs (Cooper, 1979; and Fu \& Jones, 2008).

\footnotetext{
*Corresponding author: author@email.org
} 
An idea that is not compatible with the prevalent values and norms of a social system will not be adopted as rapidly as an innovation that is compatible (Rogers, 1983). The adoption of an incompatible innovation often requires the prior adoption of a new value system. An example of an incompatible innovation is the use of contraception in countries where religious beliefs discourage use of birth-control techniques, as in Moslem and Catholic nations. This research explore and examine value of innovation that is compatible with microfinance shariah environment in Indonesia.

\section{Literature review}

\subsection{NPD performance}

Godener and Soderquist (2004) identified seven areas of measurement that were related to NPD which are financial performance measurements, customer satisfaction measurements, process management measurements, innovation measurements, strategic measurements, technology management measurements and knowledge management measurements. Sherman et. al., (2005) utilized six performance variables in their investigation. Of these six variables, product prototype development proficiency, product launch proficiency and design change frequency were process-oriented performance variables. While variables like market forecast accuracy and technological core competency fit were grouped as performance competencies, the only standalone variable was product development cycle time. Ledwith and O'Dwyer (2009) reported that new product performance is measured in terms of market-level measures, financial measures, customer acceptance measures, product-level measures and timing measures. Liu et. al., (2005) identifed three performance measures are as follows, (1) new product life cycle; (2) new product sales and profits; and (3) time to market for new product. We use marketing performance measures proposed by Akroush (2012) in the present study by exogen aksen method (Suliyanto, 2018).

\subsection{NPD innovation}

Innovation is vital to the survival of modern corporations (Ko, To, Zhang, Ngai, \& Chan, 2011). Rogers (1983) defined an innovation as an idea, practice, or object that is perceived as new by an individual or other unit of adoption. A product, service, or process can be the subject of innovation (Bhoovaraghavan and Vasudevan 1996). Schumpeter (1934) classifies innovations in two types: (1) radical and (2) incremental. Radical innovations are those originating from the process of creative destruction, a term coined to explain technological or market paradigm break throughs, shifting to something completely new and that can be represented by a product or a process. Product innovativeness refers to the level of perceived newness, originality, and uniqueness of a product (Garcia \& Calatone, 2002). For any organization, NPD innovation is crucial in achieving the success. Vinayak \& Kodali (2014) proposed six elements NPD innovation, (1) product innovation; (2) process innovation; (3) market innovation; (4) service innovation; (5) behavioral innovation; and (6) managerial innovation.

Product innovation is often referred to as the novelty and meaningfulness of new products introduced to the market in a timely fashion (Wang and Ahmed, 2004). Product innovation is critical to product success which in turn is highly related to sustainable business success, providing great opportunities for businesses in terms of growth and expansion into new areas (Cooper, 2000; Henard and Szymanski, 2001). Process innovation refers to the introduction of new production methods and new technology that can be used to improve production processes (Wang and Ahmed, 2004). Maravelakis et. al., (2006) 
emphasized that process innovation may result in product innovation and likewise product innovation may force process innovation, an inference that product innovation and process innovation are strongly correlated. In our study, process innovation constructs have been taken as those related to product development process issues concerning production methods and the distribution cycle.

Market innovation is the newness of approaches that organization adopts to enter and exploit the targeted market, i.e. innovation related to market research, advertising and promotion as well as identification of new market opportunities and entry into new markets (Wang and Ahmed, 2004). Market innovation is central to product innovation and likewise, product innovation maintains a central focus for product newness. Here, we refer to market innovation in the context of novelty of market-oriented approaches. Similarly, service innovation refers to the differences and novelties that can be built into the dimensions of intangible service offerings (Zolfagharian and Paswan, 2008). In service innovation, activities are undertaken to deliver core services so as to attract more consumers (Oke, 2007), which in turn tend to create a new revenue streams. Behavioral innovation in the organization is directly related to the people and their practices. Here, innovation is brought in to the social system of an organization like focusing on the innovative practices, culture, the overall internal receptivity to new ideas and innovation adapted by individuals and teams in the organization. Managerial innovation practices focuses more on leadership/senior management's role in building the organizational structure, administrative processes and enabling the human resources toward an innovative culture. In the present study, management strategy on innovation, administration or leadership innovation, focus on feasibility studies or risk-taking attitude of management, support for knowledge management, organization's characteristics and motivation of people to innovate were taken as constructs of managerial innovation.

\subsection{Value of innovation basis on shariah}

Service science is the study of service systems and of the co-creation of value within complex constellations of integrated resources (Spohrer et. al., 2007, 2008). Service is the application of competences (knowledge and skills) by one entity for the benefit of another (Vargo and Lusch, 2004, 2006). This definition provides a fresh perspective for understanding economic phenomena, by implying that value is created collaboratively in interactive configurations of mutual exchange. It centers on the participants, processes, andresources that interact to create value in service systems. So value and value creation are at the heart of service and are critical to understanding the dynamics of service systems and to furthering service science. But value is an elusive term.

Marketing basics highlight the importance of understanding different consumer segments and relating to their needs (Kotler and Armstrong, 2006). Mirroring the holistic view of Islamic legislation through its prime underpinning objectives (maqasid ashshari'ah) and seeing Islam not only as a culture but as creed ('aqidah), worship ('ebadat), interactions (mu'amalaat), and morality (akhlaq), El- Bassiouny (2014) attempted to set a humble precedent aimed at presenting a macro-marketing view (see p. 46) of the potential implications of Islamic marketing according to the macro-level and integrated approach of the spirit and heart of Islam, namely the sources and goals of Islamic shari'ah. Overall depiction of the transcendental values integration model discussed in El-Bassiouny (2014).

The "maqasid ash-shari'ah" of preservation of self, intellect, posterity, wealth, and faith represent the soul of Islamic legislation that permeate its inherent value system, and offer a broad framework for actions and deeds consistent with its morals, priorities, and ideals (ElBassiouny, 2015). Based service dominant logic (Vargo \& Lusch, 2006) and Islamic religiusity (El-Bassiouny, 2015), we proposed measure in the present study as value of 
innovation basis on shariahwith the following five statements, (1) create values religiusity to stakeholders; (2) use a spiritual brand character; (3) prioritization of values religiusity; (4) co-creation business based shariah values; and (5) create values religiusity system, preservation of self, intellect, posterity, wealth, and faith.

\subsection{Product innovation advantage}

Quality of the new product is perhaps the most important factor affecting success (Cooper and Kleinschmidt, 1987). We mentioned previously that quality control is more challenging for the service firm than for the manufacturing firm. Unfortunately, attempts by service firms to ensure consistency in quality through standardization decouple the service personnel from customers, encourage the domination of NSD by operations, reduce the influence of marketing and the understanding of customer needs (Lovelock, 1984, 1983; Mahajan, et. al., 1994).

Further, in comparison with their manufacturing counterparts, service firms are less efficient in the innovation process, face greater customer and competitor uncertainties, and greater incompatibility of innovations with customer requirements and firm competencies (Carman and Langeard, 1980; Brentani, 1993; Easingwood, 1986; Edget, 1993). These factors are predicted to result in lower competitive advantage/quality for new services in comparison with new products. In addition, services firms have relatively greater difficulty in sustaining advantage compared to manufacturing firms.

Consequently, whereas perceived advantage is the number one factor affecting new product success, its effect on success of new services is less profound (Cooper, et. al., 1991). This research use differen, unique, innovativeness, and quality as indicators variable product innovation advantage.

\subsection{Product launch success}

A prime innovation success factor is the proficiency of process activities such as idea screening, market, technical and financial assessments, and launch (Cooper, et. al., 1991; Cooper, et. al., 1987; and Dwyer, et. al., 1991). Although, the greater interaction between service providers and customers should lead to better awareness and understanding of customer requirements in new service development (NSD), other factors militate against this. Patent protection of intellectual property in services is not nearly as effective as in products. New services can be copied as easily and quickly by competition.

Managers of services firms do recognize the need for launch activities. such as market tests, but dispense with them because of the high cost, service being a copy of competitors, difficulty of producing test market conditions, and the need to beat competition to market (Morone and Berg, 1993).

We use five indicators as measurement product launch success. They are easily, quickly, interest, intention, and use. Customer easily and quickly to adopt new product launch, then customer interest and intention to use toward new produk. Finnally, customer use new product in the early launching.

\section{Proposed model and hypotheses}

Figure 1 introduces the paper's proposed model and its related hypotheses. 


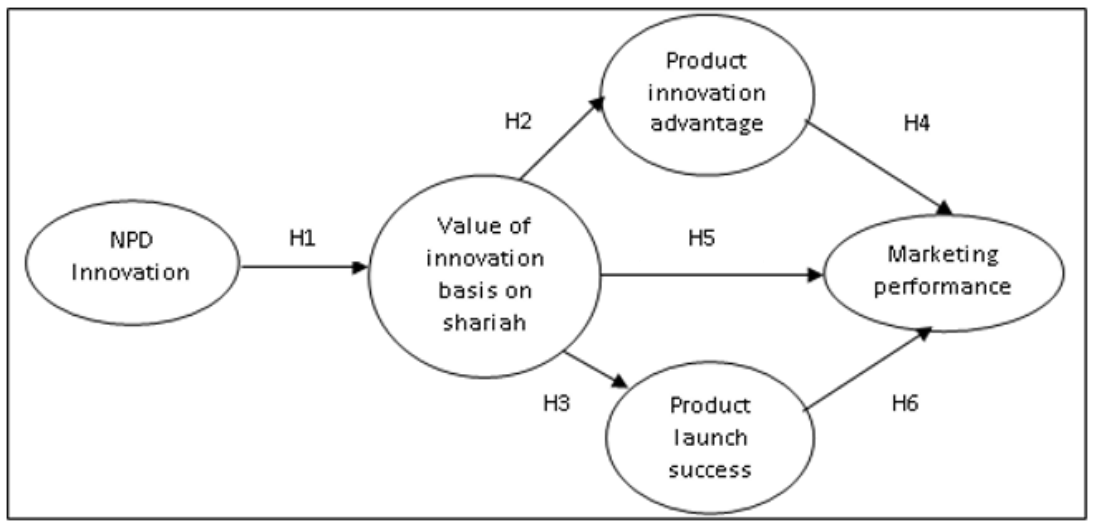

Fig. 1. Propose research model.

According to the model, we proposed six hypotheses, (1) NPD Innovation is positively associated with value of innovation basis on shariah; (2) Value of innovation basis on shariah is positively associated with product innovation advantage; (3) Value of innovation basis on shariah is positively associated with product launch success; (4) Product innovation advantage is positively associated with marketing performance; (5) Value of innovation basis on shariah is positively associated with marketing performance; (6) Product launch success is positively associated with marketing performance.

\section{Research methods}

Table 1. Construct and indicator construct.

\begin{tabular}{|c|l|l|}
\hline No & \multicolumn{1}{|c|}{ Construct } & \multicolumn{1}{c|}{ Indicator construct } \\
\hline 1 & NPD Innovation & Newness/novelty/originality/uniqueness \\
& & Administration/leadership innovation \\
& & Customer focus/customer relationship management \\
& & After-sales support services \\
& & Employees individual innovativeness \\
\hline 2 & Value of Innovation & Mu'amalat (special worship) \\
& Basis on Shariah & 'Ebadaat (general worship) \\
& & Innovativeness \\
& & Creativeness \\
& & Human well-being \\
\hline 3 & Product Innovation & Differen \\
& Advantage & Unique \\
& & Innovativeness \\
& & Quality \\
\hline 4 & Product Launch & Easiliy \\
& Success & Quickly \\
& & Interest \\
& & Intention \\
& & Use \\
\hline 5 & Marketing & Product launch on time \\
& Performance & New product speed to market \\
& & Sales new product \\
& & Market share \\
& & Marketing benefit \\
\hline
\end{tabular}


Purposive sampling is applied to this study. The questionnaires will be given to only the managers of LKMS (the board of shariah micro finance) in Pekalongan and Banyumas, Indonesia with total 171 managers from 27 LKMS (Baitul Maal wa Tamwil, Baitul Tamwil, Kospin Jasa Shariah, and KSPP Shariah).

\section{Result}

With regard to construct validity, as recommended by Hair et. al. (2012), exploratory factor analysis (EFA) and confirmatory factor analysis (CFA) were used to assess constructs validity. All the research items were subjected to EFA. An index of Kaiser's measure of sampling adequacy (overall MSA $=0,867$ ) and Bartlett's test of sphericity Sig. 0,000 suggested that factor analysis is appropriate for analyzing the data. Based on eigenvalue greater than 1, the results of EFA indicate that the research items loaded on five factors, four relective and one formative (NPD Innovation). To validate the findings that emerged from using EFA, the four factor model was evaluated by CFA using smartPLS 3.0.

Table 2. VIF values dan outer weights NPD innovation.

\begin{tabular}{|l|c|c|}
\hline \multicolumn{1}{|c|}{ NPD Innovation } & VIF & Outer Weights \\
\hline Newness/novelty/originality/uniqueness & 1,855 & 0,055 \\
\hline Administration/leadership innovation & 1,707 & $0,252^{*}$ \\
\hline Customer focus/customer relationship management & 1,911 & 0,087 \\
\hline After-sales support services & 2,577 & 0,047 \\
\hline Employees individual innovativeness & 2,601 & $0,597 * *$ \\
\hline New transaction methods & 2,577 & $0,237 *$ \\
\hline
\end{tabular}

$* * \mathrm{p}<0,01 * \mathrm{p}<0,05$

Evaluate outer model for NPD Innovation shown in Table 2. VIF values is not between $5-10$, administration/leadership innovation and new transaction methods was significant $(\mathrm{p}<0,001)$, and employees individual innovativeness was significant $(\mathrm{p}<0,005)$.

Table 3. $\mathrm{R}^{2}$ values.

\begin{tabular}{|l|c|c|}
\hline \multicolumn{1}{|c|}{ Constructs } & R Square & Adjusted R Square \\
\hline Product launch success & 0,698 & 0,694 \\
\hline Product innovation advantage & 0,027 & 0,014 \\
\hline Marketing performance & 0,667 & 0,653 \\
\hline Value of innovation basis on shariah & 0,736 & 0,732 \\
\hline
\end{tabular}

To evaluate inner model using R2, we calculate Q2, and Goodness of Fit (GoF). Value of $\mathrm{Q} 2=0,974$ and $\mathrm{GoF}=0,575$. Accordingly, research model is fit and robust to examine hypotheses (Tenenhaus, 2004). 


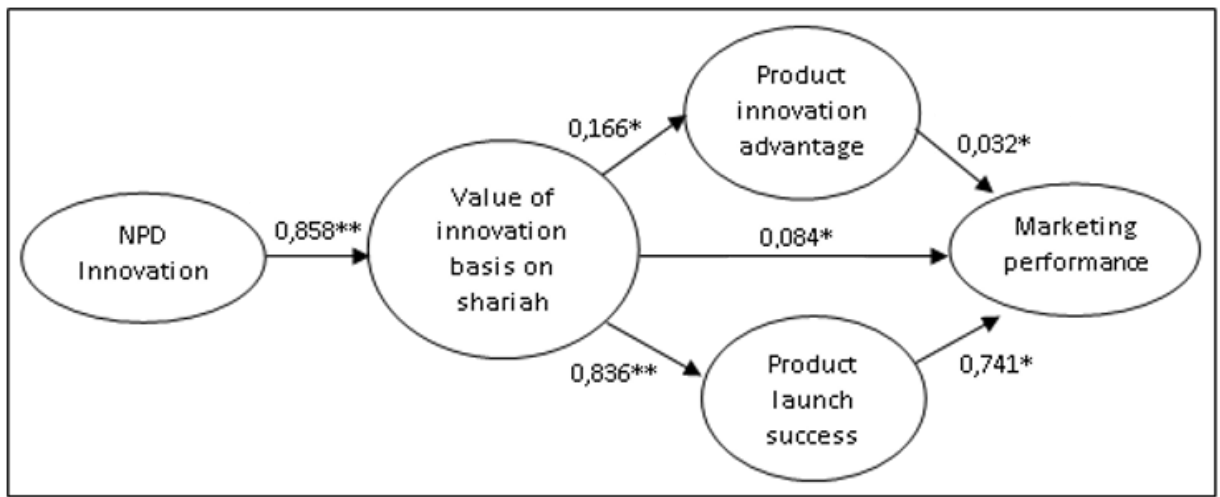

Fig. 2. Result from the structural equation analysis. Note: ${ }^{*} \mathrm{p}<0,05 * * \mathrm{p}<0,01$.

\section{Direct, indirect, and total effect}

NPD Innovation significantly affect toward value of innovation basis on shariah, and value of innovation basis on shariah indirect significantly affect toward marketing performance. Value of innovation basis on shariah affect toward product launch success, and product launch success affect toward marketing performance.

Table 4. Direct, indirect, and total effect

\begin{tabular}{|c|c|c|c|c|c|}
\hline Relationship & Direct & Indirect & Total & T Statistics & P Values \\
\hline NPDI $\rightarrow$ VoIBoS & $0,858^{* *}$ & - & $0,858^{* *}$ & 41,861 & 0,000 \\
\hline VoIBoS $\rightarrow$ PIA & $0,109 *$ & - & $0,109^{*}$ & 3,050 & 0,029 \\
\hline VoIBoS $\rightarrow$ PLS & $0,836^{* *}$ & - & $0,836^{* *}$ & 25,404 & 0,000 \\
\hline PIA $\rightarrow$ MP & $0,049^{*}$ & - & $0,049^{*}$ & 2,427 & 0,041 \\
\hline VoIBoS $\rightarrow$ MP & $0,084^{*}$ & $0,624 * *$ & $0,709^{* *}$ & 3,026 & 0,037 \\
\hline PLS $\rightarrow$ MP & $0,741^{* *}$ & - & $0,741^{* *}$ & 5,410 & 0,000 \\
\hline NPDI $\rightarrow$ PLS & - & $0,717 * *$ & $0,717 * *$ & 20,199 & 0,000 \\
\hline NPDI $\rightarrow$ PIA & - & 0,142 & 0,142 & 1,036 & 0,301 \\
\hline NPDI $\rightarrow$ MP & - & $0,608^{* *}$ & $0,608^{* *}$ & 9,962 & 0,000 \\
\hline
\end{tabular}

$* * \mathrm{p}<0,01 * \mathrm{p}<0,05$

NPDI $=$ New product development innovation

VoIBos $=$ Value of innovation basis on shariah

PIA $=$ Product innovation advantage

PLS $=$ Product launch success

$\mathrm{MP}=$ Marketing performance 
Table 5. Exploratory factor analysis and confirmatory factor analysis.

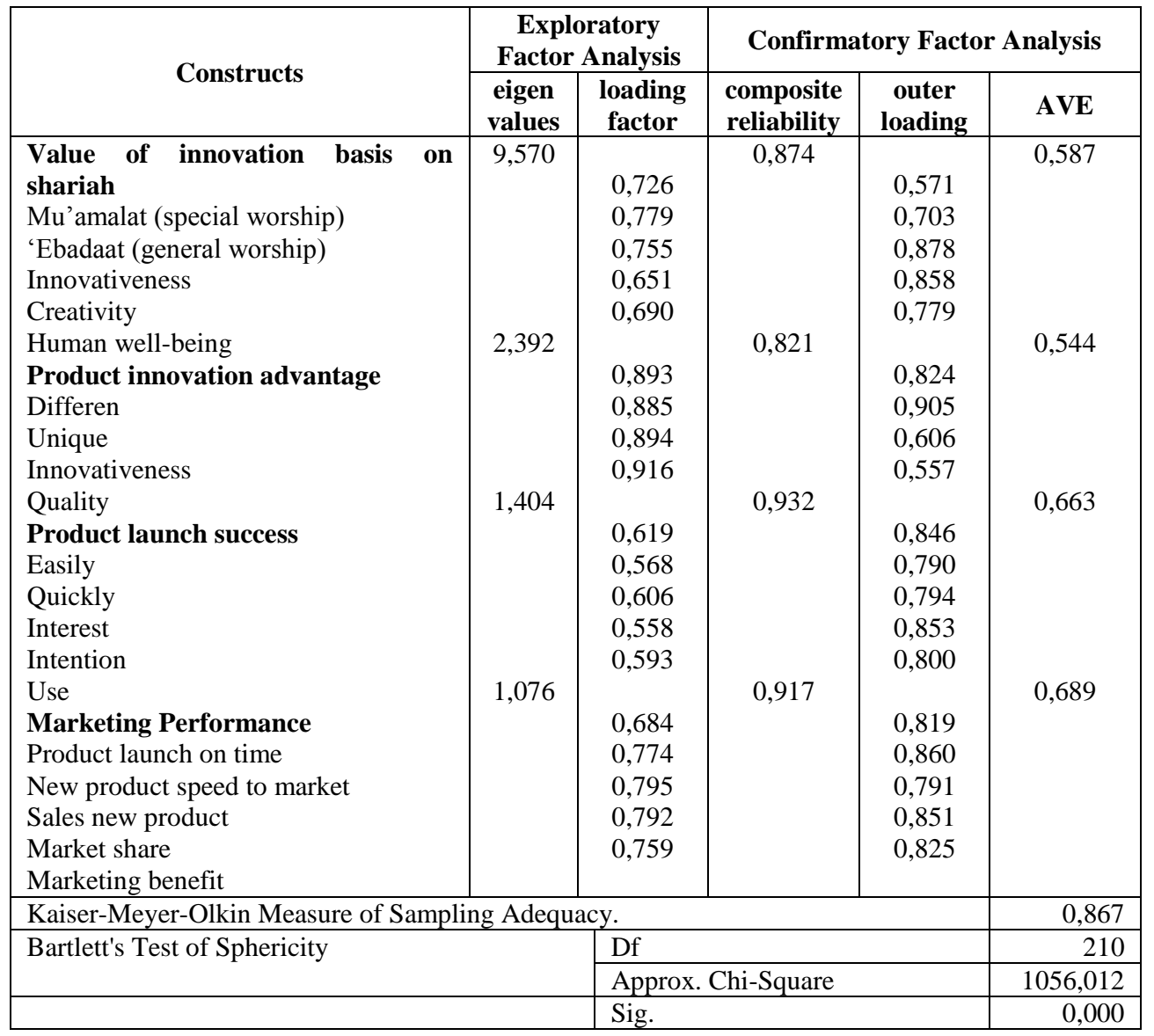

Table 6. Examine hypotheses.

\begin{tabular}{|l|c|c|}
\hline \multicolumn{1}{|c|}{ Relationship } & Coefisien & p values \\
\hline $\begin{array}{l}\text { H1: New product development innovation } \rightarrow \text { Value of innovation } \\
\text { basis on shariah }\end{array}$ & 0,858 & $0,000^{* *}$ \\
\hline $\begin{array}{l}\text { H2: Value of innovation basis on shariah } \rightarrow \text { Product innovation } \\
\text { advantage }\end{array}$ & 0,109 & $0,029^{*}$ \\
\hline H3: Value of innovation basis on shariah $\rightarrow$ Product launch success & 0,836 & $0,000^{* *}$ \\
\hline H4: Product innovation advantage $\rightarrow$ Marketing performance & 0,049 & $0,041^{*}$ \\
\hline H5: Value of innovation basis on shariah $\rightarrow$ Marketing performance & 0,084 & $0,037^{*}$ \\
\hline H6: Product launch success $\rightarrow$ Marketing performance & 0,741 & $0,000^{* *}$ \\
\hline SRMR & 0,097 & \\
\hline d_ULS & 3,525 & \\
\hline d_G1 & 2,301 & \\
\hline d_G2 & 1,906 & \\
\hline Chi-Square & 605,797 & \\
\hline NFI & 0,952 & \\
\hline rms Theta & 0,179 & \\
\hline
\end{tabular}


$* \mathrm{p}<0,05 * * \mathrm{p}<0,01$

\section{Discussion}

The NPD Innovation that formed from six dimensions as a whole, positively affects toward value of innovation basis on shariah, but only managerial innovation, behavioral innovation, and process innovation are significantly. This indicates that indirectly NPD Innovation affect toward marketing performance. There is a positive and significant effect of NPD Innovation toward value of innovation basis on shariah, value of innovation basis on shariah positively affects toward product launch success, and product launch success positively affects toward marketing performance. Shariah values are referred to the theory Islamic Religiosity, developed by El-Bassiouny (2015) in the concept of transcendental values integration, states that the process of developing shariah value, especially in the service of a company based on shariah involves value co-creation activities that have a positive impact on marketing activities (in this case supporting research results).

Vargo (2006) argues that, there is a value creation process in instilling trust in customers when marketing or selling new products resulting from innovation and product development. With regard to mediation variable, as recommended by Baron and Kenny (1986), in the first order shown that both value of innovation basis on shariah and product launch success mediated between NPD Innovation and marketing performance.

\section{Conclusion}

The conclusions of the research are the creation of value of innovation basis on shariah values and product launch success mediating the relationship between NPD Innovation and NPD Performance in the board of sharia microfinance, it must be corroborated by the trust of customers in the name of products that have a spiritual character. Second order research as recommendation in future, and explore compatibility value innovation in the large objects.

\section{References}

1. M. N. Akroush, Compet. Rev. 22, 343 (2012)

2. K. Atuahene-Gima, J. Prod. Innov. Manag. 13, 35 (1996)

3. R. M. Baron and D. A. Kenny, J. Pers. Soc. Psychol. 51, 1173 (1986)

4. S. Bhoovaraghavan, A. Vasudevan, and R. Chandran, Manage. Sci. 42, 232 (1996)

5. P. Bicen, S. Kamarudin, and W. H. A. Johnson, J. Bus. Res. 67, 2877 (2014)

6. R. J. Calantone, K. Chan, and A. S. Cui, J. Prod. Innov. Manag. 23, 408 (2006)

7. J. M. Carman and E. Langeard, Strateg. Manag. J. 1, 7 (1980)

8. R. G. Cooper, J. Mark. 43, 93 (1979)

9. R. G. Cooper and E. J. Kleinschmidt, J. Prod. Innov. Manag. 4, 169 (1987)

10. R. G. Cooper, Res. Technol. Manag. 43, 38 (2000)

11. R. G. Cooper and U. de Brentani, J. Prod. Innov. Manag. 8, 75 (1991)

12. L. Dwyer and R. Mellor, J. Prod. Innov. Manag. 8, 39 (1991)

13. N. El-Bassiouny, J. Bus. Res. 69, 569 (2016)

14. N. El-Bassiouny, J. Bus. Res. 67, 42 (2014) 
15. E. Fang, J. Mark. 72, 90 (2008)

16. F. Fu, E. Jones, and W. Bolander, J. Pers. Sell. Sales Manag. 28, 351 (2008)

17. R. Garcia and R. Calantone, J. Prod. Innov. Manag. 19, 110 (2002)

18. A. Godener and K. E. Söderquist, R D Manag. 34, 191 (2004)

19. J. F. Hair, M. Sarstedt, C. M. Ringle, and J. A. Mena, J. Acad. Mark. Sci. 40, 414 (2012)

20. C. T. Huang and K. H. Tsai, Ind. Mark. Manag. 43, 1407 (2014)

21. E. J. Hultink and H. S. J. Robben, J. Prod. Innov. Manag. 12, 392 (1995)

22. K. K. B. Ko, C. K. M. To, Z. M. Zhang, E. W. T. Ngai, and T. L. K. Chan, J. Bus. Res. 64, 1327 (2011)

23. P. Kotler and G. Armstrong, Principles of Marketing (Prentice-Hall, Upper Saddle River: New Jersey, 2006)

24. A. Ledwith and M. O’Dwyer, J. Prod. Innov. Manag. 26, 652 (2009)

25. P. Lo Liu, W. C. Chen, and C. H. Tsai, Technovation 25, 637 (2005)

26. C. H. Lovelock, J. Mark. 47, 9 (1983)

27. R. F. Lusch and S. L. Vargo, in Serv. Log. Mark. Dialog, Debate, Dir. (2006), p. 449

28. J. Mahajan, A. J. Vakharia, P. Paul, and R. B. Chase, Int. J. Res. Mark. 11, 1 (1994)

29. E. Maravelakis, N. Bilalis, A. Antoniadis, K. A. Jones, and V. Moustakis, Prod. Plan. Control 17, 283 (2006)

30. M. R. Millson, Eur. J. Innov. Manag. 16, 317 (2013)

31. S. Mishra, D. Kim, and D. H. Lee, J. Prod. Innov. Manag. 13, 530 (1996)

32. J. Morone and D. Berg, J. High Technol. Manag. Res. 4, 123 (1993)

33. A. Oke, G. Burke, and A. Myers, Int. J. Oper. Prod. Manag. 27, 735 (2007)

34. E. Rogers, Difussion of Innovations (The Free Press, 1983)

35. D. F. L. Santos, L. F. C. Basso, H. Kimura, and E. K. Kayo, J. Bus. Res. 67, 527 (2014)

36. J. A. Schumpeter, Harvard Econ. Stud. 46, 404 (1934)

37. R. Sethi, J. Mark. 64, 1 (2000)

38. J. D. Sherman, D. Berkowitz, and W. E. Souder, J. Prod. Innov. Manag. 22, 399 (2005)

39. J. Spohrer, P. P. Maglio, J. Bailey, and D. Gruhl, Computer (Long. Beach. Calif). 40, 71 (2007)

40. J. Spohrer, S. L. Vargo, N. Caswell, and P. P. Maglio, The service system is the basic abstraction of service science, in Proceedings of the 41st Annual Hawaii International Conference on System Science, January, (2008)

41. Suliyanto, Metode penelitian bisnis untuk skripsi, tesis, dan disertasi (ANDI, Yogyakarta, 2018)

42. M. Tenenhaus, S. Amato, and E. V. Vinzi, XLII SIS Sci. Meet. 739 (2004)

43. S. L. Vargo and R. F. Lusch, J. Mark. 68, 1 (2004)

44. S. L. Vargo, P. P. Maglio, and M. A. Akaka, Eur. Manag. J. 26, 145 (2008)

45. K. Vinayak and R. Kodali, Meas. Bus. Excell. 18, 39 (2014)

46. C. L. Wang and P. K. Ahmed, Eur. J. Innov. Manag. 7, 303 (2004)

47. N. L. Warren and A. Sorescu, J. Mark. 81, 64 (2017) 
48. M. Zolfagharian and A. Paswan, J. Serv. Mark. 22, 338 (2008) 